\title{
Application of Magnetized Water Irrigation for Agricultural Products
}

\author{
Fengyun $\mathrm{Ma}^{1,2,3 *}$ \\ ${ }^{1}$ Key Laboratory of Silviculture of Shandong Province, Forestry College of Shandong Agricultural University, China \\ ${ }^{2}$ Shandong Provincial Key Laboratory of Soil Erosion and Ecological Restoration, Forestry College of Shandong Agricultural University, China \\ ${ }^{3}$ Taishan Forest Ecosystem Research Station, China
}

Submission: January 17, 2020; Published: January 22, 2020

"Corresponding author: Fengyun Ma, Shandong Agricultural University, Shandong, China

\section{Opinion}

Magnetic phenomena are common in nature. With the rapid development of magnetic biology, researches on magnetized water theory and applied technology have been carried out in many places in the world, and significant progress has been made in basic experimental materials and microscopic mechanism. There is no unified conclusion on the mechanism of magnetized water in the academic circle. However, many studies showed that the magnetic field intensity, magnetization time, raw water quality and water velocity and other factors have important influences on the physical and chemical properties of magnetized water.

Regular water can become magnetized when it passes through a magnetic field of a certain strength perpendicular to the magnetic line at a certain speed. After water is magnetized, the original structure of water is changed, which changes the physical and chemical characteristics of water molecules to some extent, such as the transformation of macromolecular clusters into individual water molecules or dimers, and the reduction of the expression tension coefficient of water molecules, thus promoting the growth and development of plants and the improvement of environment. The crystallization of minerals in the soil due the small molecules Increases permeability and solubility in cell metabolism which promotes the absorption and utilization of nutrients in soil by plants. Therefore, magnetized water irrigation provides a new way to increase crop yield and improve site environment, which not only increases the research and application in agricultural and forestry production, but also enriches the research content of biomagnetism.

Since the 1970s, magnetized water has been applied to agricultural production in countries in the world, and the research scope involves food crops, fruits and vegetables, edible fungi and poultry. The results showed that magnetized water had significant effects on soil improvement, seed germination, crop stress resistance and crop yield. Therefore, the organic combination of magnetized water treatment technology with the development and utilization of low-quality water resources and the improvement of soil quality is of great significance for the efficient utilization of magnetized water, agricultural production increment and quality improvement. Based on field experiment and laboratory test research magnetized water irrigation (such as saline water and brackish water, water containing cadmium) soil micro ecological environment, mineral nutrient transport, plant photosynthetic performance plant growth, yield and quality characteristics were studied by many researchers. The cationic dynamics of mesophyll cells, root tip meristem and elongation region were observed in real time by noninvasive micrometry. The characteristics of bacterial community structure in continuous cropping and cadmiumcontaminated soil were analyzed by high-throughput sequencing. Soil microenvironment, yield composition and flavor nutrition of different fruits and vegetables under continuous cropping mode were determined and analyzed. The physiological and ecological responses of the difficult rooting trees were measured in real time by magnetizing devices with different magnetic field intensities. The effects of magnetized water irrigation on soil physical properties, enzyme activity, mineral nutrient content and plant biological characteristics of salinized soil and cadmium-polluted soil were also studied. Through these researches, researches try to clarify the mechanism of plant biology and physiological response to micro ecological environment after the irrigation of magnetized water. Though magnetized water irrigation has been used to improve agricultural production and many researches have done to study the mechanisms of bio-magnetism, much of it remains unknown and further researches should be done for us to learn more about bio-magnetism. 
This work is licensed under Creative Commons Attribution 4.0 License DOI: 10.19080/JOJHA.2020.01.555598

Your next submission with Juniper Publishers
will reach you the below assets
- Quality Editorial service
- Swift Peer Review
- Reprints availability
- E-prints Service
- Manuscript Podcast for convenient understanding
- Global attainment for your research
- Manuscript accessibility in different formats
( Pdf, E-pub, Full Text, Audio)
- Unceasing customer service
Track the below URL for one-step submission
https://juniperpublishers.com/online-submission.php

